\title{
1 \\ Global Allies in a Changing World
}

\author{
Michael Wesley
}

In October 2001, in response to the 9/11 terrorist attacks on the United States, US forces invaded Afghanistan, the country from which the attacks had been planned and coordinated. Operation Enduring Freedom, the invasion and subsequent stabilisation and state-building project in Afghanistan, saw the United States supported by the largest-ever coalition of its allies: 10 from Europe and two from Asia. ${ }^{1}$ Over the next 13 years, US allies from Asia and Europe planned, fought and worked side by side in unprecedented numbers and intensity, battling a rising Taliban insurgency and supporting the consolidation of the Afghan Government and security forces. In the process, the North Atlantic Treaty Organization (NATO) in Europe and the San Francisco System in Asia became global allies, collaborating not only in Afghanistan but also in the stabilisation of Iraq, the setting up of the Proliferation Security Initiative to prevent transnational nuclear proliferation, and enforcing anti-piracy patrols in the Gulf of Aden. Japan, South Korea, Thailand, the Philippines, Australia, New Zealand and Pakistan were designated 'major non-NATO allies' and began attending issue-specific discussions among NATO members in Brussels.

1 Canada, although not in Europe, was a contributing NATO member; New Zealand, although no longer a member of ANZUS, had been designated a non-NATO ally by the administration of Bill Clinton in 1997. 
A decade after the invasion of Afghanistan, in a speech to a joint sitting of the Australian parliament, US President Barack Obama proclaimed that 'the United States is turning our attention to the vast potential of the Asia Pacific region ... the United States will play a larger and longterm role in shaping this region and its future.' By mid-2012, the administration's resolve had been written into strategic policy: the United States would 'rebalance' its attention away from the Middle East towards the Asia-Pacific region, where 60 per cent of its naval, space and cyber assets would be positioned. ${ }^{3}$ The American rebalance caused more than a ripple of disquiet among US allies in Europe. Many responded to the understandable implication that a rebalance towards Asia would mean a diminution of America's commitment to its security partnerships elsewhere. For many NATO members, the Chinese challenge to America's Pacific primacy was remote, whereas Russia's increasingly assertive and aggressive policies towards its near neighbours, Georgia, the Ukraine and NATO members in the Baltic states, represented the most profound challenge to European security since the end of the Cold War. Ironically at the same time in Asia, many security elites expressed scepticism about the seriousness of the rebalance. They questioned whether the United States would really be able to disentangle its forces and attention from the ongoing instability in the Middle East and North Africa and, even if it could, whether it would have the resolve to face down an increasingly confident and demanding China in the western Pacific. These concerns are likely to continue given the US air campaign against the Islamic State of Iraq and Syria (ISIS), and its recent recommitment of forces to Europe in the aftermath of Russian aggression in Ukraine.

Thus, in the first decade of the 21st century, US allies in Europe and Asia had traced the full arc of their new condition of interdependence, first tasting the benefits of collaboration and solidarity; and then the anxieties of competing for US commitment, attention and resources. Never before had NATO and the San Francisco system been so mutually significant. In 1949, the United States reversed 150 years of eschewing alliances by agreeing to a multilateral pact to shore up postwar Europe against an antagonistic and expansive Soviet Union. At the time, Washington had categorically ruled out a similar commitment in Asia, and rebuffed

2 'Text of Obama's Speech to Parliament', Sydney Morning Herald, 17 Nov. 2011, www.smh.com. au/national/text-of-obamas-speech-to-parliament-20111117-1nkcw.html.

3 US Department of Defense, 'Sustaining US Global Leadership: Priorities for 21st Century Defense', p. 2. 
attempts by anxious wartime partners, such as Australia, to be allowed inside the NATO tent, at least at a consultative level. Gradually, however, whether as a condition for a peace deal with a rehabilitated Japan, or under the threat of communist expansion into the Pacific, it reneged, signing a series of alliances with Japan, South Korea, Taiwan, the Philippines, Thailand, Australia and New Zealand from 1951. Unlike NATO, these would be bilateral (or trilateral, in the case of Australia, New Zealand, United States Security (ANZUS)), and their operative clauses in general much less compelling as security guarantees than NATO's Article 5.

For the next half-century, the two alliance systems operated in isolation. While some NATO members joined the United Nations' enforcement action in Korea in the 1950s, it was not a NATO operation. None of the San Francisco allies showed the slightest interest in supporting the Asian commitments of European powers, even though Britain contributed to the postcolonial stabilisation and defence of Malaya. The Vietnam War in the 1960s and 1970s mobilised the San Francisco allies minus Japan, but not a single NATO member. Iraq's invasion of Kuwait in 1990 saw US allies from Europe and Asia come together to support a UN enforcement operation, as in Korea, but the experience was brief and had little effect on the different worlds of the two alliance systems. NATO became consumed by its post-Cold War expansion and the wars of the former Yugoslavia, while the San Francisco system seemed in decline, with Taiwan's loss of its formal alliance with the United States in 1978, New Zealand's expulsion from ANZUS in 1986, and the closure of US bases in the Philippines in 1992. As the new century dawned, it was not an attack on any smaller ally, but on the superpower anchor of both alliance systems that brought about a new era of interdependence. Suddenly the rationale of both alliance systems had shifted from deterring and defeating state-based aggression to addressing state dysfunction and battling transnational violent extremism. The new reality in a unipolar world was that allies of the sole superpower had to anticipate, understand and integrate with their major ally's new strategic imperatives. As a wounded America rose in fury, its long-time allies faced a choice of rising with it or being cast aside. For the first time, the thoughts and actions of remote US allies on the other side of the world became of abiding importance.

The Global Allies Project, on which this volume is based, brought together strategic scholars from eight countries allied to the United States to discuss challenges in alliance dynamics and management. The project is a response to a major lacuna in this new era of alliance interdependence. 
While today America's European and Asian allies are intimately aware of each other's thinking on terrorism and counterinsurgency, counterproliferation, piracy and sea-lane security, cyber-threats and hybrid challenges, there has been remarkably little discussion of the challenges of alliance management among the allies of the United States. While there are large and inevitable differences between different alliances, there are also significant commonalities, including dilemmas of commitment, trust and risk management, the difficulties of managing American expectations and domestic political resistance, issues of defence spending and interoperability, and reconciling alliance commitments with other foreign policy interests. For 60 years, US allies have managed these issues in mutual isolation, and sometimes in competition with each other. The Global Allies Project seeks to add a crucial tile to the alliance interdependence puzzle, by systematically comparing the challenges and processes of alliance management across a range of long-standing US allies in Europe and Asia.

Rather than look backwards, however, the Global Allies Project looks toward the future of alliance management in Europe and Asia. While it is impossible to tell whether another 9/11 will happen to reinforce the interoperation of Asian and European allies of the United States, we believe there are structural forces at play that will reinforce the interdependence of the two alliance systems, and that make the case for comparing alliance management dynamics an enduring one. It is the purpose of this introductory chapter to explore what some of these structural forces are. In the sections ahead, I examine the imperatives of alliance policy in an era of relative US power decline, of regional and global order challenges by revanchist powers, and of the changing balance of costs and benefits in alliance commitments. Rather than establish a framework for the detailed alliance-specific case studies that follow, this chapter is intended to set the general scene against which those case studies can be read.

\section{Declining Relatives}

The perennial debates about the relative decline of American power serve to underline how central US primacy has been for the post-World War II global order. The unprecedented and probably never-to-be replicated post-World War II power lead that allowed the United States to craft a world order according to its preferences, convince a large number of other states of its legitimacy, and defend it against its opponents, has been 
eroding steadily over the past 70 years. The collapse of the Soviet Union led to two decades of unipolarity but, unlike after World War II, the United States was not able to craft a stable or enduring 'new world order' as its first post-Cold War president promised. Indeed, the past two decades have demonstrated the complexity and intractability of threats to world order and the limits of American power to craft durable solutions to them.

Perhaps the greatest challenge to American primacy has been the pervasive uncertainty within its own policymaking system about what US power can achieve and how and when it should be wielded. As the dust of the Soviet collapse settled, Washington was nonplussed at the seeming puniness of those challengers that arose in defiance of George HW Bush's new world order: a jumped-up Iraqi strongman; Serbian paramilitary thugs; an unhinged, jumpsuit-wearing North Korean dictator; and drugaddled Somali gangs. But, despite not even approaching the seriousness of the Cold War's crises, these new challenges would prove anything but routine matters for the sole superpower. American forces had little trouble in winning kinetic victories; what American power couldn't achieve was enduring solutions that were acceptable to liberal consciences or the liberal order. What these frustratingly enduring challenges produced was a rising tide of criticism within the US of how those in charge of US foreign policy were handling the sword and shield of the Republic.

And so, American foreign policy lurched between extremes of aggression and restraint as the 21 st century began. The George W Bush administration brought to power a critical mass of neoconservatives who believed that it was imperative to use the unipolar moment to reshape the world for another era of American dominance and liberal peace. American power could not only recast an infinitely pliable world, it could create new realities. Those who resisted would be crushed, those who objected would be cast aside; those who were onboard would benefit from the new reality. But the early swagger of the neoconservatives turned sour as global opinion turned against the projected invasion of Iraq, and as coalition troops in both Afghanistan and Iraq faced rising insurgencies. The 2008 presidential election campaign saw both Republican and Democratic contenders criticise the Bush administration's recklessness in its use of force, its rhetorical excesses, and its cavalier treatment of long-time allies and partners of the United States. Bush's successor, Barack Obama, replaced confrontation with conciliation with those seen to be resisting the liberal global order - the Muslim world, China, Russia, Iran — and became as hesitant to use force as his predecessor had been bellicose. 
Yet Obama's foreign policy registered few successes. Despite his search for a series of 'resets', Russia, China and Iran became more assertive and defiant and a series of Muslim states in the Middle East and Africa succumbed to an even more brutal jihadist insurgency. The candidates in the 2016 presidential election have united in distancing themselves from the Obama approach to the use-and particularly the non-useof American power.

The backdrop to the oscillation of approaches to American power has been the slow vanishing of the unipolar era due to a combination of factors. One was the real demonstration of the limits of American power in Afghanistan and Iraq; unlike the Vietnam War, which was a proxy conflict against two Cold War opponents, these have been 21 st-century insurgencies combining a millennial ideology, brittle structures of domestic order, deep sectarian divisions, and global support networks facilitated by new social media. The United States ran down its stocks of goodwill, public support, defence financing and tolerance for casualties, while the challenges of state dysfunction and Islamist insurgencies continue unabated. Meanwhile the global financial crisis mired the United States, Europe and Japan in debt, while dealing a major blow to the legitimacy of Western liberal dominance of the global economy. In the aftermath of the crisis, it became less and less controversial to observe the growing economic heft of emerging economies, particularly in Asia; on current trends, the United States will yield its century-long position as the world's largest economy during this decade. China is already the world's largest economy in purchasing power parity terms, the world's largest importer of minerals and energy, the world's largest exporter, the world's largest manufacturer, the world's largest trading nation, and the primary trading partner for 130 countries. In the meantime, its military spending has been increasing rapidly, leading some observers to argue that China represents a more profound threat to US primacy than the Soviet Union ever did.

At this time of relative decline, the United States faces some profound challenges to the liberal global order it founded. The Arab 'Spring' of 2009-11 did not bring about a spread of representative democracy in the Middle East but, rather, the collapse of political order amid a virulent fanatical insurgency, deepening sectarian divisions and the growing assertiveness of regional powers. The global financial crisis bequeathed a chronically weak and unstable global economy, in which the status quo powers in the international economic order are faced with mounting debt and pervasive weaknesses in their currencies, and more and more 
countries are looking to decidedly illiberal means of returning to stability and growth. ${ }^{4}$ Meanwhile, three powers have begun new forms of military adventurism across the Eurasian landmass. Using the pretext of protecting ethnic Russian minorities outside its borders, Russia launched attacks on Georgia in 2008 and Ukraine in 2014, dismembering parts of both states' territories. In the aftermath of the invasions of Afghanistan and Iraq, Iran used the resulting chaos to extend its influence into Iraq, Syria, Lebanon and Yemen. Iranian forces are currently at war in Iraq, Syria and Yemen. In eastern Asia, China asserted territorial claims in the East China Sea and the South China Sea and across the line of control with India. Taken together, these actions represent a challenge to the territorial order across Asia, agreed in 1991 in Europe, 1915 in the Middle East and 1945 in East Asia. And each of these three revisionist powers, having closely watched US air and sea power in action since the end of the Cold War, has been patiently building up its anti-area access and denial (A2AD) capabilities-a development that has created an uncertainty of response in the United States and its allies. Finally, the world now faces new threats to the global information commons. The increasingly interconnected information and control systems of societies have proven extremely vulnerable to criminal and coercive attack; at the same time, the resort of major states to authoritarian control over their information systems threatens a possible Balkanisation of the global information network.

The combination of falling US relative power and rising systemic threats to that power creates a paradox of rising indispensability and falling credibility for the United States among its allies. On the one hand, Washington is unsure whether a decisive show of resolve will only further illustrate the ineffectiveness of US power $a$ la Iraq and Afghanistan; on the other, each case of perceived American hesitance is taken as more evidence of the recession of American primacy. Meanwhile, American allies face challenges to the liberal order with a growing sense that any effective response must involve the full complement of allied commitment and solidarity, but such are the expectations of allies in Europe, Asia and the Middle East that the American response will almost inevitably be found wanting in each theatre. While Stephen Walt is right to observe that

4 The rise of statist economic models is the most prominent and worrying of these; see Ian Bremmer, The End of the Free Market: Who Wins the War Between States and Corporations?, New York: Portfolio, 2010. 
hard balancing against the unipole is unlikely even under conditions of declining relative power, the dilemmas of alliance commitment and credibility are no less diminished. ${ }^{5}$

\section{Shoring Up the Liberal Order}

The frequency of US allies' and partners' recent exhortations on the need to defend the liberal order is a compelling sign that they are increasingly worried about its integrity. The states system seems to be under attack from above and below. In the Middle East and North Africa, jihadist insurgencies explicitly reject the borders drawn between Muslim societies. Their goal of a transnational caliphate, if successful, seeks to recast the postcolonial order across the Muslim world. In place of state territorial boundaries would be a single confessional divide between the society of believers and those of the unbelievers; across this divide would exist a state of perpetual war.

Empire states exist in the Caucasus and the Western Pacific that are determined to expand their boundaries, either through formal annexations of territory or through the creation of spheres of influence. President Vladimir Putin's Russia grieves the collapse of the Soviet Union and the loss of territory, in Europe and Central Asia, but especially in the Caucasus. Both Georgia and Ukraine made the fatal mistake of seeking to align their countries more with the West and less with Russia; such a challenge to the Russian sphere of influence was met by direct aggression and the annexation of strategically crucial territory. In the Western Pacific, China increasingly views the 'first island chain', stretching from Japan through the Ryukyus and Taiwan to the Philippines as a scheme imposed on it by the Western postwar settlement, to hem China in through an archipelago controlled by states hostile to it and allied with the United States. Beijing is increasingly intent on overturning this postwar settlement, absorbing Taiwan, building sea control in the South China Sea, and nibbling away at the Ryukyus via its claims to the Senkaku/Diaoyu Islands. As in the Caucasus, it is a process of challenging the status quo through unilateral and unpredictable faits accompli.

5 Stephen M Walt, 'Alliances in a Unipolar World', World Politics, vol. 61, no. 1, Jan. 2009, pp. 86-120. doi.org/10.1017/S0043887109000045. 
In both Europe and Asia, the United States and its allies face a real paradox of liberal order maintenance that makes their commitments to uphold the liberal order both conditional and unconditional. The conditionality of the liberal order arises from its commitment to certain values, such as democracy, the rule of law and free assembly and exchange, as well as its belief that the liberal order will not be complete until there is universal adherence to these claims. Real problems arise when the liberal order is dependent on illiberal regimes for its stability. In these cases, support for authoritarian allies is always conditional and unpredictable; the fate of Egypt's President Hosni Mubarak showed that long-term US support can be suddenly withdrawn when one's authoritarian nature is suddenly on stark display. The parallel unconditionality of the liberal order arises from its commitment to liberal values and their eventual universality. This means that an attack on these values anywhere is taken to be an attack on them everywhere, creating mounting demands on the United States and its allies to 'do something' when these values are under assault. Whether or not actual strategic interests are at stake becomes secondary and, once committed to, the draining defence of liberal values becomes very hard to walk away from.

Both the conditionality and the unconditionality of liberal-order maintenance create real opportunities for those challenging the order. For a start, by definition these are states that do not identify with the order or its maintenance; they are able to free ride on those aspects they can benefit from, while avoiding, resisting or undermining elements they find threatening. The conditionality of US support for authoritarian or problematic allies creates opportunities for new partnerships, such as those developing between China and Saudi Arabia or between Russia and Pakistan. The unconditionality of US and allied commitments to defending liberal values generates a perpetual state of strategic chaos, as the upholders of the liberal order perpetually disperse their forces and resources based on maps not of interests but of values. The fanatical jihadists in the Muslim world can dependably draw the 'Great Satan' and its allies into what they believe to be a millennial battle on their own turf simply through a growing catalogue of outrages. 


\section{Alliance Costs and Benefits}

The long history of regarding alliances in accounting terms, weighing up the costs and risks against the benefits and assurances they provide, is deeply embedded in political logics and the public mind. Arguably, one of the main reasons for the longevity of US alliances has been that their benefits have been seen to vastly outweigh their costs. For much of their history, US alliances have been relatively costless for both America and its allies. While it has become commonplace for American defence policymakers to complain of their allies' underspending on defence, there is little to suggest that America's alliance commitments contributed to higher US defence spending than would otherwise have been the case, while for much of their tenure, most US basing commitments in Asia and Europe have been financially supported by its smaller allies. For those smaller allies, there has rarely been any serious doubt that their alliances with the United States allowed them a level of security out of all proportion to their direct investments in the military and intelligence capabilities; or that an ending of their alliance with the United States would necessitate much greater defence expenditure to acquire the same level of protection. ${ }^{6}$ Even when there were losses of blood and treasure in fighting alongside the United States in regional conflicts, smaller allies were aware that such exercises allowed their forces to maintain cutting-edge capabilities and their agencies access to inner realms of American intelligence and strategy.

An argument could be made that, for both America and its allies, there has been a convenient security-political trade-off to be made through their security relationships. Alliances in Asia and Europe provided the United States with political cover for its security commitments; the willingness of major powers to partner with US security commitments across the globe provided a sense of universal legitimacy to US strategic goals, both during the Cold War and after. For allies, the US guarantee provided security cover for their political alignments with the United States and the West; this meant that European states living under the shadow of the Iron Curtain and Asian states concerned about the spread of communist insurgencies could reassure themselves that they were safer as staunch members of the West than they would be if they tried to become neutral

6 Of course, there have been arguments that US alliances have actually detracted from allies' security by making them more prominent targets of attack. 
and avoid the confrontation. Nor has there been a strong sense, on the part of the United States or its smaller allies, that the alliance has acted as a significant constraint on their freedom of foreign policy initiative. ${ }^{7}$

The politics of alliance maintenance have been subtle and varied across the various allied states. The virtues of American strategic power tend to erode quickly among both American and allied publics soon after that power is deployed. Consequently, alliance maintenance has always been an exercise in 'two-level games' in which allied governments must try to maintain domestic political acceptance for a range of alliance commitments that are regarded as acceptable by US policymakers. ${ }^{8}$ Repeatedly, the two-level logic of alliance maintenance, in combination with the alliance accounting (or insurance) metaphor, has led to allies casting the alliance as the objective, rather than the means, of foreign and strategic policy. This meant that the United States was often joined in the exercise of coercion not because allies particularly subscribed to the objectives of coercion with the same intensity as the United States, but because they believed, and could argue to their publics, that 'alliance maintenance' required such a commitment to be shown.

There are three dangers in this approach. The first is that the alliance becomes heavily politicised. Controversial or costly actions taken in coalition with the intention of investing in alliance maintenance will end up increasing opposition to the alliance among both American and allied publics. The second cost is for the United States, because the imperative of alliance maintenance will mean that it finds itself paired with coalition partners who are less interested in the actual strategic objectives at hand than they are in keeping their major ally happy. This has been a problem in both Iraq and Afghanistan, where US allies have made decisions to pull out of operations long before the situation has been regarded as stable enough to justify withdrawal. The third danger of this approach to alliances is a tendency for both the United States and its allies to turn situations into tests of alliance credibility. The best example of this was the response to the 9/11 attacks, which the George W Bush administration clearly signalled was a test of how much allies were committed to American security and

7 See, for example, Michael Beckley, 'The Myth of Entangling Alliances: Reassessing the Security Risks of US Defense Pacts', International Security, vol. 39, no. 4, Spring 2015, pp. 7-48. doi. org/10.1162/ISEC_a_00197.

8 See Robert D Putnam, 'Diplomacy and Domestic Politics: The Logic of Two-Level Games', International Organization, vol. 42, no. 3, Summer 1988, pp. 427-60. doi.org/10.1017/ S0020818300027697. 
American global-order preferences. The result was broad buy-in to the invasion of Afghanistan, a country in which no Asian or European ally had any strategic stake. A couple of years later, Bush raised the alliance commitment bar by setting his sights on an invasion of Iraq, based on highly tenuous connections to the 9/11 attacks and global security more broadly. In this case, the Bush administration was in effect asking its allies not only to place their alliance ties above their own non-existent interests in Iraq, but also above their commitments to the rule of international law and the substantial opposition of their own populations. In the end, two European allies (Britain and Spain) and one Asian (Australian) joined the invasion, all three using the demonstration of their solidarity with Washington to gain significant concessions from a grateful Bush administration. Ultimately, perhaps reflecting some realism on the part of the Bush administration, there were few negative consequences for allies that did not join the Iraq invasion or its subsequent stabilisation phase.

There are signs that the relatively costless nature of alliances is starting to be questioned in both Europe and Asia. In the face of direct Russian and Chinese challenges to the status quo and to American primacy, both the United States and its respective allies are aware of difficult choices. ${ }^{9}$ During the 2016 US presidential election campaign, Republican candidate Donald Trump committed to requiring US allies in Europe and Asia to pay more of the shared cost of their own security or risk the attenuation of those alliances. It remains to be seen whether the president will deliver on these pledges. Victor Cha observes that, in Asia, an alliance security dilemma has developed: whereas US-alliance-initiated regional efforts are portrayed as latent strategies for containing China, regioninitiated attempts to engage China are seen as attempts to exclude the United States. ${ }^{10}$ A similar situation may be emerging in Europe, where US initiatives aimed at deterring further Russian adventurism are being seen by some as only increasing Russian hostility, while European efforts to engage with Russia are seen by others to be weakening NATO. Beyond this, the utility of alliances is starting to be questioned. In Asia, every Chinese provocation is now taken as a litmus test of American resolve

9 See, for example, Stefanie V Hlatky \& Jessica T Darden, 'Cash or Combat? America’s Asian Alliances During the War in Afghanistan', Asian Security, vol. 11, no. 1, Mar. 2015, pp. 31-51. doi.org/10.1080/14799855.2015.1006360; Tongfi Kim, 'The Role of Leaders in Intra-Alliance Bargaining', Asian Security, vol. 10, no. 1, Mar. 2014, pp. 47-69. doi.org/10.1080/14799855.2013. 874338 .

10 Victor D Cha, 'Complex Patchworks: US Alliances as Part of Asia's Regional Architecture', Asia Policy, no. 11, Jan. 2011, pp. 27-50. 
and alliance commitment, a situation that bears heavily on American policymakers and cedes a great deal of initiative to Beijing. In Europe, there is a sense that NATO has been of little utility in dealing with three pressing challenges: the war in the Levant, Russian adventurism in the Caucasus, and the growing refugee crisis. It seems that alliances, so often seen as the ends of security policy, are now being found wanting as the means to greater security in more challenging security environments in both Europe and Asia.

\section{Conclusion}

Against this background, the comparison of alliance-management challenges faced by European and Asian allies of the United States unfolds as a rich exercise. While clearly acknowledging the differences between the two regions - the nature of treaty commitments, multilateralism versus bilateralism, strategic geography and levels of development-what has been truly fascinating has been the similarities between the two regions. Indeed, there have been more than a few points of convergence: the dilemmas of dealing with 'grey zone'/hybrid threats, the challenges of interoperability and the tension between regional and global focus for alliance action. But perhaps the most intriguing convergence has been in relation to alliance structures: whereas in Asia a system of bilateral alliances is slowly plurilateralising as US allies develop security partnerships with each other; in Europe there has been an observable process of NATO allies quietly developing their own bilateral security relationships with the United States.

The chapters that follow have been developed by security specialists and consider their own country's alliance with the United States. They constitute a rich collection of reflections on particular alliances, but arguably an even richer collective reflection on some of the generic challenges of managing well-matured alliances with the world's sole superpower. 
This text is taken from Global Allies: Comparing US Alliances in the 21st Century, edited by Michael Wesley, published 2017 by ANU Press, The Australian National University, Canberra, Australia. 